http://doi.org/10.35784/iapgos.2079

\title{
EXPERIMENTAL STUDY OF NATURAL GAS HUMIDITY CONTROL DEVICE
}

\author{
Yosyp Bilynsky ${ }^{1}$, Oksana Horodetska ${ }^{1}$, Svitlana Sirenko $^{2}$, Dmytro Novytskyi $^{1}$ \\ ${ }^{1}$ Vinnytsia National Technical University, Faculty of Information Communication, Radio Electronics and Nanosystems, Vinnytsia, Ukraine, \\ ${ }^{2}$ Vinnytsia Trade and Economic Institute of Kyiv National Trade and Economics University, Faculty of Trade, Marketing and Services, Vinnytsia, Ukraine
}

\begin{abstract}
The means of measuring humidity based on the use of the ultrahigh frequency method have been recently gaining widespread use, because of its simple, robust construction and high measuring accuracy. We used the advanced waveguide ultrahigh frequency method of measuring the moisture content of natural gas which, in contrast to the known the use of a traveling wave in a waveguide, is proposed. In this case, the interaction with waves of the ultrahigh frequency range changes the dielectric properties of the gas, and this change is registered. On the basis of an improved ultrahigh frequency method of humidity measurement, a device for natural gas humidity control using a traveling wave in a waveguide is proposed. The investigations have shown that a comparative channel increased the measurement accuracy, as a two-channel system-in contrast to a single-channel - eliminates the instability of the value of the input signal supplied to the generator. The principle of operation of a natural gas humidity control device that contains an ultrahigh frequency generator, attenuators, waveguide tees, a waveguide section for comparison, temperature sensor and pressure switches for the comparative and measuring channels, a measuring cuvette, amplifier, microprocessor, and display unit is described. A mathematical model of a natural gas humidity control device, which takes into account the values of the dielectric permittivity of the measuring gas and reference channels and contains correction factors for temperature, the use of which increases the accuracy of humidity measurement, is proposed. The lower and upper calibration points of the natural gas humidity control device are defined. The influence of correction factors for the temperature at the measurement error of the humidity is analyzed.
\end{abstract}

Keywords: ultrahigh frequency method, traveling wave, natural gas humidity control device, experimental research

\section{BADANIA EKSPERYMENTALNE NARZEDZI DO POMIARU KONTROLI WILGOTNOŚCI GAZU ZIEMNEGO}

\begin{abstract}
Streszczenie. Ostatnio przyrzady do pomiaru wilgotności oparte na metodzie mikrofalowej sq szeroko stosowane ze względu na ich prosta, niezawodnq konstrukcję $i$ wysoka dokładność pomiaru. W pracy wykorzystano ulepszona mikrofalowa metodę falowodów mikrofalowych do pomiaru wilgotności gazu ziemnego, która, $w$ przeciwieństwie do znanych, sugeruje zastosowanie fali podróżnej w falowodzie. Jednocześnie podczas interakcji z falami mikrofalowymi zmieniaja się właściwości dielektryczne gazów, zmiana ta jest rejestrowana. W oparciu o ulepszona mikrofalowa metodę pomiaru wilgotności zaproponowano sposób pomiaru kontroli wilgotności gazu ziemnego za pomoca fali przemieszczającej się w falowodzie. Przeprowadzono badania, które wykazaty, że obecność kanału porównawczego umożliwiła zwiększenie dokładności pomiaru, ponieważ system dwukanałowy, w przeciwieństwie do systemu jednokanatowego, eliminuje niestabilność wartości sygnału wejściowego dostarczanego przez generator. Opisano zasadę działania przyrzadu pomiarowego do pomiaru wilgotności gazu ziemnego, który zawiera generator mikrofalowy, tlumiki, trójniki falowodu, sekcje falowodu do porównania, czujnik temperatury i ciśnienia, przełaczniki kanałów porównawczych i pomiarowych, cele pomiarowa, wzmacniacz, procesor, urządzenie wskaźnikowe. Zaproponowano model matematyczny środków pomiaru kontroli wilgotności gazu ziemnego, który uwzględnia wartość stałej dielektrycznej gazu kanałów pomiarowych i odniesienia oraz zawiera współczynniki korekcji temperatury, których zastosowanie poprawia dokładność pomiaru wilgotności. Określane sa dolne i górne punkty kalibracji zakresu pomiarowego wilgotności gazu ziemnego. Analizowany jest wplyw współczynników korekcji temperatury na błą pomiaru wilgotności.
\end{abstract}

Słowa kluczowe: metoda mikrofalowa, fala podróżna, środki pomiaru kontroli wilgotności gazu ziemnego, badania eksperymentalne

\section{Introduction}

Improving the accuracy of natural gas quality control parameters, reducing consumption and reducing losses affect the energy security of Ukraine. Therefore, permittivity monitoring of the quality parameters of natural gas is an extremely important and urgent task. One of the main parameters which is monitored is humidity $[2,11]$.

There are many methods and means of determining humidity. The most common method is condensation, which has a number of limitations. Namely, the method is applied to determine the temperature of the dew point moisture in gases not containing dropping liquid and the hydrocarbon dew point not exceeding the dew point of moisture more than $5^{\circ} \mathrm{C}$. In addition, the temperature of a sampling line should be not less than $3^{\circ} \mathrm{C}$ higher than the estimated (expected) temperature of the dew point of the gas $[9,11]$. Failure to comply with the above requirements significantly increases the measurement error. These limitations do not exist in the ultrahigh frequency method of humidity measurement in natural gas.

The aim of this work is to develop a device for measuring natural gas humidity control with high accuracy and to perform experimental studies.

\section{Statement of the problem}

Measurement of the humidity of gases using ultrahigh frequencies is a kind of dielectric method in which the change in the dielectric properties of the gases are evaluated by their interaction with decimeter, centimeter and millimeter radio waves. According to the adopted classification method, ultrahigh frequency moisture measurement methods are divided into optical, resonance, waveguide, heartbeat, probe, and others $[2,8,11]$.

The most promising is the waveguide method, where in waveguide line transmission with the help of an ultrahigh frequency generator at a wavelength generator to excite the bulk wave and install in the transmission line mode of standing waves. Before measuring, the waveguide cell is evacuated and the measuring line is in the position of the node of the standing wave. Then the researched gas is put into the waveguide cell, which causes a shift in the minimum of the standing wave. The displacement of the node of the standing wave allows the dielectric permittivity of the gas of interest to be determined at a known wavelength in the waveguide and wavelength in free space. The disadvantage of this method are the dimensions of the waveguide cell [2, 8]. This poses the problem of new approaches to improve humidity devices significantly, aimed at improving their accuracy and sensitivity.

\section{Ultrahigh frequency method of measuring humidity in natural gas}

An improved ultrahigh frequency method of natural gas humidity control is proposed. In contrast to the known methods, the use of a traveling wave in the waveguide is proposed. When interacting with waves in the ultrahigh frequency range, the dielectric properties of the gases change. Ultrahigh frequency conversion measuring moisture in natural gas is to absorb the UHF signal, and therefore the power measurement of this signal at the output of the waveguide, thus changing the humidity of the gas by use of a traveling wave. 
The authors propose a mathematical model of an ultrahigh frequency transmitter humidity natural gas. A detailed explanation of the mathematical model is given in $[5,7,10]$. Research based on the power of a traveling wave from the absolute humidity of water vapor at different values of the length of the passage of the ultrahigh frequency signal in a humid environment subject to temperature and pressure is conducted. It is established that with the increase of the absolute humidity of the water vapor, the radiation power falls off exponentially.

\section{Device for natural gas humidity control}

On the basis of studies a natural gas humidity control device (NGHCD) developed on the basis of the ultrahigh frequency traveling wave method, the structural diagram is shown in Fig. 1.

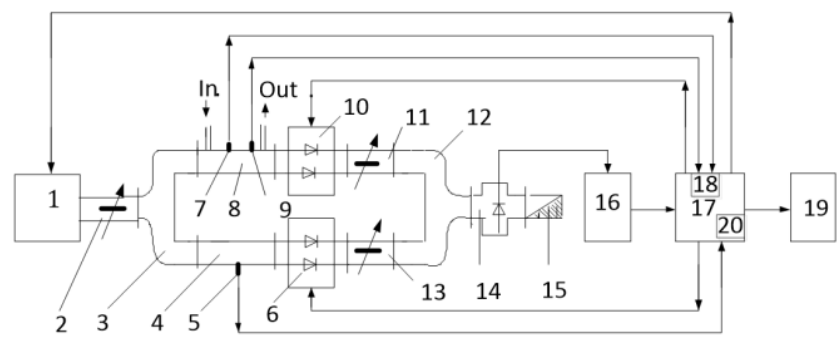

Fig. 1. Block diagram of a natural gas humidity control device

A NGHCD is double-channeled and consists of an ultrahigh frequency generator 1 , an attenuator 2 , a tee waveguide 3 , the waveguide comparison section (comparative cell) 4 , temperature sensors 5 and 9 , the switch of the comparative channel 6 , the pressure sensor measuring the waveguide section 7 , the waveguide measuring section (measuring cell) 8 , the switch of the measuring channel 10, attenuator measuring channel and channel comparison of 11 and 13, respectively, of the waveguide tee 12 , the diode section 14, the agreed load 15, an amplifier 16, a microprocessor 17, an ADC 18, an indicator device 19, and an output port 20 $[5,17]$.

In the experimental study of the NGHCD, a measuring cuvette was filled with an air mixture (later air), which corresponds to the density and the dielectric permittivity of natural gas, at a pressure of $1 \mathrm{~atm}[6,16]$. Since the air in the room basically consists of the sum of indicators of the attenuation of dry air and water vapor, the attenuation of the controlled air is

$$
K_{\kappa}=K_{c}+K_{w}
$$

where $K_{c}$ - attenuation of dry air; and $K_{w}-$ attenuation of water vapor, which is equal to:

$$
K_{w}=\sqrt{\frac{1}{2} \cdot \frac{p \cdot 273,15}{760 \cdot T} \cdot \frac{\rho_{v n}}{\rho_{v}} \cdot\left(\sqrt{\left(\varepsilon_{1}^{\prime}-1\right)^{2}+\left(\varepsilon_{1}^{\prime \prime}-1\right)^{2}}-\left(\varepsilon_{1}^{\prime \prime}-1\right)\right)}(2)
$$

where $p$-pressure; $\mathrm{t}$ - temperature (in degrees Kelvin) of the test environment; $\rho_{v, n}-$ absolute humidity of water vapor; $\rho_{v}-$ density of water; $\varepsilon_{1}{ }^{\prime}, \varepsilon_{1}{ }^{\prime \prime}-$ real and imaginary components of complex dielectric permittivity.

The dielectric permittivity of water vapor at a temperature of $20^{\circ} \mathrm{C}$ is $\varepsilon^{\prime}-1=0.0000619$, and $\varepsilon^{\prime \prime}-1=0.0000314$ [13]. It also depends on the temperature.

According to $[8,14]$, we adjust the dielectric permittivity of water vapor depending on the temperature of the controlled air inside the measuring cuvette:

$$
K_{w t}=K_{w}-K_{t 2} \cdot t
$$

where $K_{w t}$ - temperature attenuation of the controlled air, taking into account the deviation of the gas temperature in the measuring cell from $0^{\circ} \mathrm{C} ; K_{t 2}$ - temperature correction factor, for water vapor, $K_{t 2}=0.0000036825 ; t-$ numerical value of the temperature in the measuring cell (in degrees Celsius).
The rate of attenuation of dry air, taking into account the adjustment for temperature is known, and equal to $K_{c t}$. Therefore, the attenuation index of the controlled air, taking into account the adjustment for temperature $K_{t \kappa}$ will be:

$$
K_{t \kappa}=\left(K_{w}-K_{t 2} \cdot t\right)+\left(K_{c}-K_{t 1} \cdot t\right)
$$

And the attenuation coefficient $a_{t 2}$ of the controlled air, taking into account the temperature adjustment:

$$
a_{t 2}=\left(\left(K_{w}-K_{t 2} \cdot t\right)+\left(K_{c}-K_{t 1} \cdot t\right)\right) \cdot Z
$$

where $Z=\frac{2 \pi L}{\lambda}, L$ - length of the comparison cuvette, $\lambda$ - wavelength emitted by the ultrahigh frequency generator 1 , and $\lambda=0.03 \mathrm{~m}$

The voltage $U_{b}$ of the measuring channel at the output of the amplifier 16 will be equal to:

$$
U_{6}=\frac{1}{2} K_{1} \cdot K_{2} \cdot K_{3} \cdot K_{5} \cdot K_{6} \cdot K_{7} \cdot K_{8} \cdot K_{9} \cdot K_{10} \cdot P_{0} \cdot e^{-K_{t x} \cdot Z}
$$

where $K_{l}$ - attenuation coefficient of the high-frequency electromagnetic wave (HEW) by the attenuator; $K_{2}-$ loss factor connected with the passage of the waveguide section of the waveguide tee; $K_{3}$ - loss factor connected with the passage through the waveguide section of the comparison cuvette in a vacuum state; $K_{5}, K_{6}, K_{7}$ - coefficients of losses during the passage of HEW through the switch, waveguide attenuator section, branch of the waveguide tee, respectively; $K_{8}, K_{9}, K_{10}-$ conversion factors of the diode section, current of the diode $I_{D}$ to voltage $U$, conversion factor of the amplifier, respectively; $P_{0}-$ power of the HEW coming from the generator $[1,15]$.

Similarly, the voltage $U_{n}$ of the comparison channel is:

$$
U_{n}=\frac{1}{2} K_{1} \cdot K_{2} \cdot K_{3} \cdot K_{5} \cdot K_{6} \cdot K_{7} \cdot K_{8} \cdot K_{9} \cdot K_{10} \cdot P_{0} \cdot e^{-\left(K_{c}-K_{t 1} \cdot t\right) \cdot Z}
$$

The voltage $U_{n}$ and $U_{b}$ comes to the analog input of the microprocessor, where the division of signals $U_{b}$ and $U_{n}$ is done taking into account the conversion factor $K_{11}$, logarithm of the particle from division and conversion by the ADC with conversion factor $K_{12}$ to digital signal $N$. Then the mathematical model can be written as [12]:

$$
\left\{\begin{array}{l}
\ln \left(\frac{U_{n}}{U_{B}}\right)=\left(\ln K_{11}+\frac{2 \pi \cdot L}{\lambda} \cdot\left(K_{w}-K_{t 2} \cdot t\right)\right) \cdot K_{2} \\
N_{1}=\frac{K_{12} \cdot U_{B}}{U_{o n}} \cdot\left(2^{n_{0}}-1\right) \\
N_{2}=\frac{K_{12} \cdot U_{n}}{U_{o n}} \cdot\left(2^{n_{0}}-1\right)
\end{array}\right.
$$

where $N_{l}$ - binary value of the code of the n-bit ADC, which digitizes the voltage $U_{B}$ of the measuring channel; $N_{2}$ - binary value of the code of the n-bit $\mathrm{ADC}$, which digitizes the voltage $U_{p}$ of the comparison channel; $K_{2}$ - conversion factor connected with the calibration of the NGHCD.

An experimental setup of the tool has been developed for conducting experimental research. Fig. 2 shows the appearance of the sensor of the natural gas humidity device.

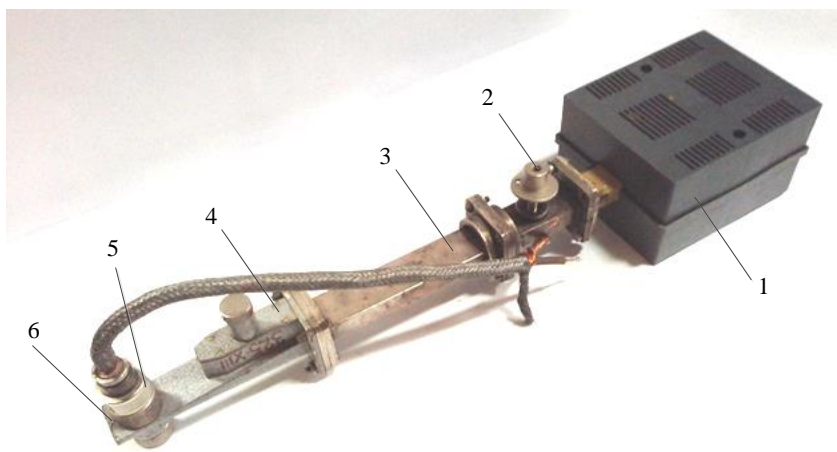

Fig. 2. Appearance of the gas humidity sensor: 1 -ultrahigh frequency generator with wavelength $\lambda=3 \mathrm{~cm}, 2$ and 4 -attenuators, 3 - measuring cuvette, 5 -diode section, 6 - agreed load 
The appearance of the humidity transducer, the PC manager and the system connections of the device are shown in Fig. 3.

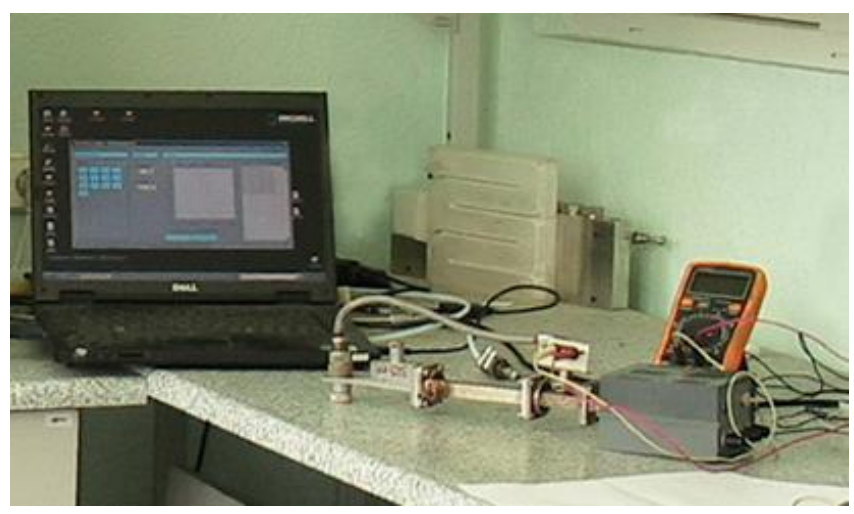

Fig. 3. Appearance of $N G H C D$

The ultrahigh frequency humidity transducer layout testing was conducted at the Ukrainian State Scientific and Production Center of Standardization, Metrology, Certification and Consumer Protection, SE "Ukrmetrteststandard", Kyiv.

Standard samples of humidity were prepared at a sample installation. As an investigated gas, air was used at a temperature of $19^{\circ} \mathrm{C}$. A UT $70 \mathrm{~B}$ Professional Digital Multimeter digital tester, with an automatic ranging switching scale, served as the indicator device for the ultrahigh frequency humidity model. The accordance of the humidity to the temperature of the dew point and absolute humidity was determined by the HumCalc.exe program.

The software on the laptop, which is part of the installation for the production of samples of gases with specific humidity content, set the humidity content of the samples based on absolute humidity and the dew point. The sample jet of the humidity content of the gas came from a silicone tube, which was connected to the nozzle of measuring cuvette 3 of ultrahigh frequency moisture.

Tests of the NGHCD were performed at a temperature of $19^{\circ} \mathrm{C}$, a pressure of one atmosphere and a gas flow rate of $10 \mathrm{l} / \mathrm{min}$. The gas consumption was $2 \mathrm{dm}^{3} / \mathrm{min}$. An exemplary gas sample was pumped continuously through the measuring cuvette of the humidity transducer.

The theoretical and experimental static characteristics are shown in Fig. 4.

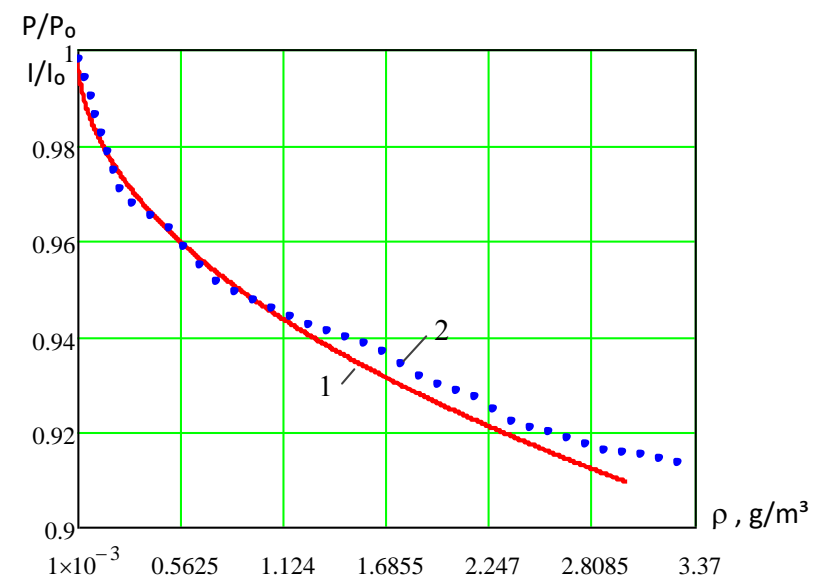

Fig. 4. Theoretical 1 and experimental 2 static characteristics

As can be seen from the figure, the deviation of the experimental dependence from the theoretical is less than $5 \%$.

\section{Definition of the lower calibration point of natural gas humidity measuring range}

To determine the lower calibration point of the range or point of "zero," it is necessary to pump dry air at a pressure of $1 \mathrm{~atm}$ into the measuring cell. With the help of attenuators 2, 11 and 13 (Fig. 1) we achieve equality indicators of voltage $U_{n}$ and $U_{6}$. To do this, in manual mode, in turn, we open and close switches 11 and 13. Then:

$$
U_{0}=\ln K_{11} \cdot K_{2}
$$

This value is recorded in the memory of the microprocessor and it will characterize the zero point calibration characteristics of the NGHCD.

This configuration of the moisture meter is carried out after manufacturing the device. During operation, with periodic inspections and verification of the metrological characteristics of the NGHCD, in this setting, it is not necessary.

\section{Definition of upper calibration points of the natural gas natural humidity measuring range}

The operation of taking the logarithm allowed to analyze exponent characteristic $U_{6}$ depending on changes of the dielectric permeability of the controlled gas atmospheres.

Therefore, it is possible to carry out primary calibration of the NGHCD at two points: at the point of "zero" absolute humidity and the point that corresponds to the absolute humidity of the air in the room where the graduation NGHCD (as in the measuring cuvette is pumped with air with this humidity). For this, a psychrometer determines the relative humidity of the air in the room where you placed NGHCD. For example, it is equal to $70 \%$ and the indoor temperature equal to $20^{\circ} \mathrm{C}$. According to these parameters online calculator HumCalc.exe will define the absolute humidity. It will be $12.111 \mathrm{~g} / \mathrm{m}^{3}$.

Since the logarithmization process linearized the exponential dependence, the calibration characteristic of the NGHCD can be constructed at two points: $W_{0}=0$ and $W=12.111 \mathrm{~g} / \mathrm{m}^{3}$.

The tangent of angle $\alpha$ of the calibration characteristic of the NGHCD will be $K_{2}=\operatorname{tg} \alpha=\frac{U_{B}}{W}$, hence:

$$
W=\frac{U_{6}}{\operatorname{tg} \alpha}
$$

According to (2):

$$
W_{0}=\ln K_{11} \cdot \frac{U_{0}}{\operatorname{tg} \alpha}
$$

Taking into account (1):

$$
W=\frac{\left(\ln K_{11}+\left(K_{w}-K_{t 2} \cdot t\right) \cdot Z\right) \cdot U_{s}}{\operatorname{tg} \alpha}
$$

Humidity $W$ depends in direct proportion on the attenuation temperature of controlled air $K_{w t}$ and is inversely proportional to the tangent of angle $\alpha$ of the calibration characteristic of the NGHCD. The upper limit of the humidity measurement range is set at the request of the customer, but it is necessary to take into account the requirement of the diode on the linear current-voltage characteristic.

After calibration of the NGHCD, microprocessor 17 is turned on automatically. In this mode, by means of switches 11 and 13, there is a sequential switching of the measuring channel and the comparison channel to measure the dielectric permittivity of the gases which exist in them. Based on these data, the microprocessor 17 calculates the humidity of the gas in the measuring cell 8 . The calculated value of gas humidity is displayed on the indicator device and can be given in the following units: absolute humidity $\left(\mathrm{g} / \mathrm{m}^{3}\right)$, dew point temperature by humidity TTРв $\left({ }^{\circ} \mathrm{C}\right)$, dew point temperature on frost TTPi $\left({ }^{\circ} \mathrm{C}\right)$, relative humidity $(\%)$, and volumetric humidity concentration (ppmV). 


\section{Analysis of temperature errors}

The indicator device displays information about the humidity of the gas with temperature adjustment. Let us consider what the error of the NGHCD will be in the absence of temperature adjustment. The analysis data are summarized in Table 1.

Table 1. Value of relative temperature error indicators

\begin{tabular}{|c|c|c|c|c|c|}
\hline $\mathbf{t}$ & $\boldsymbol{\varepsilon}_{\mathrm{w}}{ }^{\prime}-\mathbf{1}$ & $\boldsymbol{\varepsilon}_{\mathrm{w}}{ }^{\prime \prime}-\mathbf{1}$ & $\boldsymbol{K}_{w}$ & $\boldsymbol{a}_{\boldsymbol{s}}$ & $\Delta \mathbf{t}, \mathbf{\%}$ \\
\hline 1 & 2 & 3 & 4 & 5 & 6 \\
\hline$+20^{\circ} \mathrm{C}$ & 0.0000619 & 0.0000314 & 0.001937 & 0.04865 & -3.678 \\
\hline $0.0^{\circ} \mathrm{C}$ & 0.0000668 & 0.00003388 & 0.002012 & 0.05054 & ---- \\
\hline$-20^{\circ} \mathrm{C}$ & 0.00007169 & 0.00003636 & 0.002085 & 0.052375 & +3.678 \\
\hline
\end{tabular}

Columns 2 and 3 of Table 1 show the actual and imaginary values of changes in the dielectric permittivity of water vapor $\varepsilon_{\mathrm{w}}{ }^{\prime}$ and $\varepsilon_{\mathrm{w}}$ " at temperatures of $+20^{\circ} \mathrm{C}, 0^{\circ} \mathrm{C}$ and $-20^{\circ} \mathrm{C}$. In column 4 , the values of attenuation index $K_{w}$ at $+20^{\circ} \mathrm{C}, 0^{\circ} \mathrm{C}$ and $-20^{\circ} \mathrm{C}$ are calculated according to [9]. Column 5 shows the changes in exponent $a_{b}$ depending on the temperature change from $0^{\circ} \mathrm{C}$ to $-20^{\circ} \mathrm{C}$ and $+20^{\circ} \mathrm{C}$, where $a_{\theta}=\frac{2 \pi K_{w} L}{\lambda}$. Column 6 shows relative errors $\Delta t$ in the absence of temperature adjustment when changing the temperature of the controlled air from $0^{\circ} \mathrm{C}$ to $+20^{\circ} \mathrm{C}$ and $-20^{\circ} \mathrm{C}$ :

$$
\Delta t=\frac{\left(a_{\theta\left(0^{\circ} \mathrm{C}\right)} \pm a_{\theta\left(20^{\circ} \mathrm{C}\right)}\right) \cdot 100 \%}{a_{\theta\left(0^{\circ} \mathrm{C}\right)}}
$$

From column 6 , it can be seen that relative error $\Delta t$ in the absence of temperature adjustment and when the air temperature changes relative to $0^{\circ} \mathrm{C}$ by $+1^{\circ} \mathrm{C}$ and $-1{ }^{\circ} \mathrm{C}$ leads to an error of $\pm 0.18 \%$.

\section{Measurement of natural gas humidity}

Natural gas consists of $98 \div 99 \%$ methane [3, 9]. The dielectric permittivity of dry methane is equal to $\varepsilon_{\mu}{ }^{\prime}=1,000953$ at $0^{\circ} \mathrm{C}$ [13]. Dry air is pumped into the comparison cuvette 4 . The dielectric permittivity of dry air is equal to $\varepsilon_{c}{ }^{\prime \prime}=1.0006258$ at $0^{\circ} \mathrm{C}$ [13]. Accordingly, the attenuation of dry air $K_{c}$ and methane $K_{\mu}$ will be different. This must be taken into account when measuring the humidity of natural gas, both taking into account the adjustment for the dry air temperature and when adjusting for the dry methane temperature. Therefore, formula (7) will take the form:

$$
U_{2}=\ln K_{11}+\left(-a_{c}+a_{6}\right)=\ln K_{11}+\left(\left(K_{M}+K_{w}\right)-K_{t u}\right)
$$

where $K_{t M}$ - calculated attenuation index of dry methane taking into account the effect of temperature.

$$
K_{t u}=K_{c}+K_{n\left(0^{\circ} \mathrm{C}\right)}-K_{t} \cdot( \pm t)
$$

where $K_{n\left(0^{\circ} \mathrm{C}\right)}-$ correction factor at $0^{\circ} \mathrm{C} ; K_{t}$ - temperature correction factor; $t$ - numerical indicator of the temperature of the correction factor, in degrees Celsius.

So:

$$
U_{2}=\ln K_{11}+\left(\left(K_{M}+K_{w}\right)-\left(K_{c}+K_{n\left(0^{\circ} \mathrm{C}\right)}-K_{t} \cdot( \pm t)\right)\right)
$$

In Table 2, the values of the calculated coefficients of correction and error in their application are shown.

In columns 2,3 and 4,5 of Table 2 , the calculated real $\varepsilon_{\mathrm{M}}{ }^{\prime}, \varepsilon_{\mathrm{c}}{ }^{\prime}$ and imaginary $\varepsilon_{\mathrm{M}}{ }^{\prime \prime}, \varepsilon_{\mathrm{c}}{ }^{\prime \prime}$ values of the dielectric permittivity of dry methane and dry air at temperatures of $+20^{\circ} \mathrm{C}, 0^{\circ} \mathrm{C}$ and $-20^{\circ} \mathrm{C}$, respectively, are shown. Columns 6 and 7 show the calculated values of the change in attenuation index $K_{c}$ of dry air and attenuation index $K_{t M}$ of dry methane at $+20^{\circ} \mathrm{C}, 0^{\circ} \mathrm{C}$ and $-20^{\circ} \mathrm{C}$ [19]. In column 8 , the calculated values of the change in correction factor $K_{n}$ at $+20^{\circ} \mathrm{C}, 0^{\circ} \mathrm{C}$ and $-20^{\circ} \mathrm{C}$, where $K_{n}=K_{t M}-K_{c}$ are shown. In column 9 , the calculated values

\begin{tabular}{|c|c|c|c|c|c|c|}
\hline $\mathbf{t},{ }^{\circ} \mathbf{C}$ & $\varepsilon_{M}^{\prime}-1$ & $\varepsilon_{n}{ }^{\prime \prime}-1$ & $\varepsilon_{c}^{\prime}-1$ & $\varepsilon_{c}{ }^{\prime \prime}-1$ & $\boldsymbol{K}_{c}$ & $\boldsymbol{K}_{t M}$ \\
\hline 1 & 2 & 3 & 4 & 5 & 6 & 7 \\
\hline+20 & 0.0008831 & 0.00008831 & 0.00058 & 0.000058 & 0.0012026 & 0.001484 \\
\hline 0.0 & 0.000953 & 0.0000953 & 0.0006258 & 0.00006258 & 0.0012492 & 0.0015416 \\
\hline-20 & 0.0010228 & 0.00010228 & 0.0006717 & 0.00006717 & 0.0012942 & 0.0015971 \\
\hline
\end{tabular}

of temperature correction factor $K_{t}$ at $+20^{\circ} \mathrm{C}, 0^{\circ} \mathrm{C}$ and $-20^{\circ} \mathrm{C}$, where $K_{t}=K_{n\left(0^{\circ} \mathrm{C}\right)}-K_{n\left( \pm 20^{\circ} \mathrm{C}\right)}$ are shown.

Table 2. Values of adjustment coefficients and relative error in their application

Continuation of Table 2

\begin{tabular}{|c|l|c|c|c|c|}
\hline $\boldsymbol{K}_{\boldsymbol{n}}$ & $\boldsymbol{K}_{\boldsymbol{n}\left(0^{\circ} \boldsymbol{C}\right)}-\boldsymbol{K n}_{\left( \pm 20^{\circ} \boldsymbol{C}\right)}$ & $\boldsymbol{K}_{\boldsymbol{t} \boldsymbol{n}}$ & $\sum=\boldsymbol{K}_{\boldsymbol{c}}+\boldsymbol{K}_{\boldsymbol{t} \boldsymbol{n}}$ & $\boldsymbol{K}_{\boldsymbol{t} \boldsymbol{u}}-\sum$ & $\Delta \boldsymbol{K}_{\boldsymbol{t} \boldsymbol{u}} \boldsymbol{\%}$ \\
\hline 8 & \multicolumn{1}{|c|}{9} & 10 & 11 & 12 & 13 \\
\hline 0.0002814 & 0.000011 & 0.0002817 & 0.0014843 & 0.0000003 & 0.0202 \\
\hline 0.0002924 & 0.0000107 & 0.0002924 & 0.0015416 & ---- & $-\cdots--$ \\
\hline 0.0003028 & 0.0000104 & 0.0003031 & 0.0015973 & 0.0000002 & 0.0125 \\
\hline
\end{tabular}

The average temperature correction factor at a value of $t=0^{\circ} \mathrm{C}$ is calculated. The average correction factor relative to $1^{\circ} \mathrm{C}$ is $K_{t}=0.000000535$. Column 10 shows the calculated values of correction factor $K_{t n}$ at $+20^{\circ} \mathrm{C}, \quad 0^{\circ} \mathrm{C}$ and $-20^{\circ} \mathrm{C}$, $K_{t n}=K_{t\left(0^{\circ} \mathrm{C}\right)}-K_{t}( \pm t), K_{t n\left(0^{\circ} \mathrm{C}\right)}=0.0002924$ [13].

Column 11 shows the values of the sum of the attenuation of dry air and the calculated value of correction factor $\Sigma=K_{c}+K_{t n}$. In column 12, the value of the difference between the attenuation index $K_{t M}$ of dry methane and the sum of the attenuation index of dry air $K_{c}$ with the calculated value of correction factor $K_{t n}$ at $+20^{\circ} \mathrm{C}, 0^{\circ} \mathrm{C}$ and $-20^{\circ} \mathrm{C}$ is shown. In column 13, the value of relative error $\Delta K_{t n}$ when changing the temperature of the controlled wet methane relative to $0^{\circ} \mathrm{C}$ to $+20^{\circ} \mathrm{C}$ and $-20^{\circ} \mathrm{C}$, where $\Delta K_{t n}=0.0202 \%$ at $+20^{\circ} \mathrm{C}$ and $\Delta K_{t n}=0.0125 \%$ at $-20^{\circ} \mathrm{C}$ is shown.

It can be seen from column 13 that relative error $\Delta K_{t n}$ when changing the gas temperature relative to $0{ }^{\circ} \mathrm{C}$ by $+1{ }^{\circ} \mathrm{C}$ and $-1{ }^{\circ} \mathrm{C}$ leads to an error of $0.001 \%$ and $0.000625 \%$, respectively.

\section{Conclusions}

1. A natural gas humidity control device was developed in this work, the principle of which is based on the ultrahigh frequency method of moisture measurement in natural gas, in which, in contrast to the well known method, the use of a traveling wave in the waveguide is proposed. Thus, the changes in the dielectric properties of the gases in their interaction with waves in the ultrahigh frequency range are measured.

2. A mathematical model is developed for the measurement of natural gas humidity control, which takes into account the values of the dielectric permittivity of the gas measuring and channel of comparison, and contains correction factors for temperature, the use of which increases the accuracy of humidity measurement.

3. Experimental studies were carried out on the proposed device for measuring natural gas humidity control, including adjusting the humidity measurement by temperature. The analysis of the temperature error was performed, and on the basis of this, it can be concluded that to improve the accuracy of measuring the moisture content of natural gas, installing temperature sensors in the measuring and comparative waveguides is required. With the range of the technical parameters of the temperature sensors being $\pm 0.5^{\circ} \mathrm{C}$ when measuring the temperature, the accuracy of measurement of the humidity of the monitored gas does not exceed $\pm 0.09 \%$.

4. The influence of correction factors for temperature measurement error was analyzed, on the basis of which it can be concluded that the use of these coefficients allows high accuracy to compensate for the difference of the dielectric permittivity of dry methane and dry air. The error in this case when the temperature changes from $0^{\circ} \mathrm{C}$ to $10^{\circ} \mathrm{C}$ does not exceed $0.01 \%$. 


\section{References}

11] Azarov O. D., Murashchenko O. G., Chernyak O. I., Smolarz A., Kashaganova G.: Method of glitch reduction in DAC with weight redundancy. Proc. SPIE 9816, 2015, 98161T

[2] Berliner M. A.: Izmereniya vlazhnosti. Energiya, Moscow 1973.

[3] Bilenko D. I.: Kompleksnaya dielektricheskaya pronitsaemost. Plazmennyiy rezonans svobodnyih nositeley zaryada v poluprovodnikah. Sarat, 1999.

[4] Bilinsky Y., Saldan Y. R., Ogorodnik K. V., Lazarev A. A., Horodetska O. S., Zyska T., Mussabekova A.: New ultrasound approaches to measuring material parameters. Proc. SPIE 10808, 2018, 108085F, [http://doi.org/10.1117/12.2501637].

[5] Bilynsky Y., Horodecka, O., Novytskyi D.: Development of a mathematical model of a two-channel microwave measuring converter of the humidity of natural gas. Visnyk of Vinnytsia Politechnical Institute 4(145), 2019, 19-24 [http://doi.org/10.31649/1997-9266-2019-145-4-19-24].

[6] Bilynsky Y., Horodetska O., Hladyshevskyi M., Mykhalevskiy D., Grąz Ż., Duskazaev G.: Experimental investigations of the amplitude-frequency meter of the velocity flowing environment. Proc. SPIE 10808, 2018, 1080869, [http://doi.org/10.1117/12.2501614].

[7] Bilynsky Y., Horodetska O., Novytskyi D., Voytsekhovska O.: Development of a mathematical model of measuring control device of natural gas humidity. Technology audit and production reserves - vol. 2, 1(52), 2020, 42-45, [http://doi.org/10.15587/2706-5448.2020.200476].

[8] Brandt A. A.: Issledovanie dielektrikov na sverhvyisokih chastotah. Fizmatgiz, 1963.

[9] Chen Z.: Humidity sensors: a review of materials and mechanisms. Sensor Lett. 3(4), 2005, [http://doi.org/10.1166/s1.2005.045].

[10] Hraniak V. F., Kukharchuk V. V., Bilichenko V. V. et al.: Correlation method for calculation of weight coefficients of artificial neural-like networking hydraulic units' diagnostic systems. Proc. of SPIE 11176, 2019, 1-7.

\section{Prof. Yosyp Bilynsky}

e-mail: yosyp.bilynsky@gmail.com

Doctor of Technical Sciences, Professor, Head of the Department of Electronics and Nanosystems of Vinnytsia National Technical University. Author of more than 300 publications, including 11 monographs, 8 textbooks, more than 50 copyright certificates and patents for inventions and more than 200 scientific articles in professional journals, 12 of which are in the Scopus and Web of Science scientometric databases.

http://orcid.org/0000-0002-9659-7221

\section{Associate Professor Oksana Horodetska}

e-mail: horodecka.os@gmail.com

Associate Professor in the Department of Telecommunication Systems and TV Broadcasting, Vinnytsia National Technical University. Author of more than 100 publications, including 1 monograph, 8 textbooks, 20 copyright certificates and patents for inventions, more than 40 scientific articles, 6 of which are in the Scopus scientometric database and more than 40 published abstracts of international conferences.
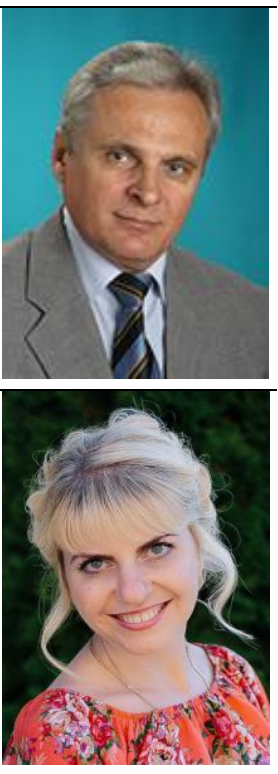

http://orcid.org/0000-0001-6929-1123
[11] Korotcenkov G.: Handbook of Humidity Measurement - Vol. 1: Spectroscopic Methods of Humidity Measurement. CRC Press 2018.

[12] Kvyetnyy R. N., Sofina O. Yu., Lozun A. V. et al.: Modification of fractal coding algorithm by a combination of modern technologies and parallel computations. Proc. SPIE 9816, 2015, 98161R.

[13] Mykhalevskiy D.V., Horodetska O.: Investigation of wireless channels according to the standard 802.11 in the frequency range of $5 \mathrm{GHz}$ for two subscribers. Journal of Mechanical Engineering Research and Developments 42(2), 2019, 50-57, [http://doi.org/10.26480/jmerd.02.2019.50.57].

[14] Osadchuk O, Osadchuk V., Osadchuk I.: The Generator of Superhigh Frequencies on the Basis Silicon Germanium Heterojunction Bipolar Transistors. 13th International Conference on Modern Problems of Radio Engineering, Telecommunications and Computer Science - TCSET, 2016, 336338.

[15] Semenov A. O., Osadchuk A. V., Osadchuk I. A., Koval K. O., Prytula M. O The chaos oscillator with inertial non-linearity based on a transistor structure with negative resistance. Proceedings of the International Conference Micro/Nanotechnologies and Electron Devices - EDM, 2016.

[16] Vasilevskyi O. M.: Calibration method to assess the accuracy of measurement devices using the theory of uncertainty. International Journal of Metrology and Quality Engineering 5 (4), (2014).

[17] Vedmitskyi Y. G., Kukharchuk V. V., Hraniak V. F. et al.: Newton binomial in the generalized Cauchy problem as exemplified by electrical systems. Proc. of SPIE 10808, 2018, 1-7.

[18] Wang J., Zhang H., Cao Z., Zhang X., Yin C., Li K., Zhang G., Yu B: Humidity sensor base on the $\mathrm{ZnO}$ nanorods and fiber modal interferometer. Proc. SPIE 9685, 968516, 2016. [http://doi.org/10.1117/12.2244482].

[19] Yakovlev K. P. (Ed.): Kratkiy fiziko-tehnicheskiy spravochnik. Fizmatgiz, 1960

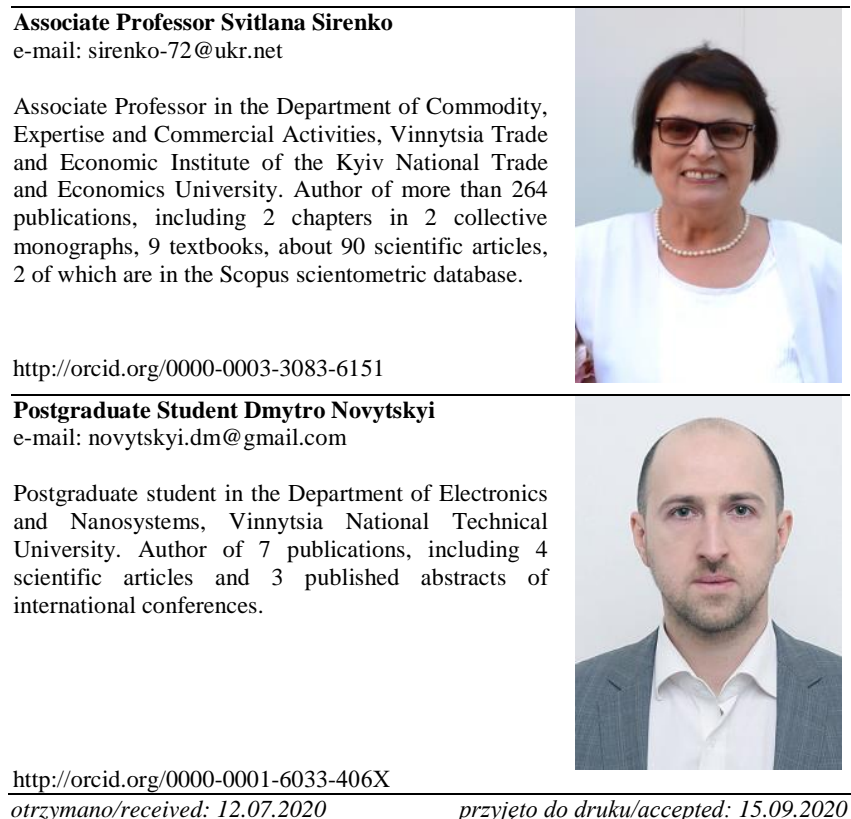

